\title{
Age-related anesthetic effect of ketamine in the chickens
}

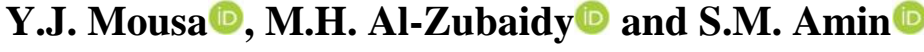

Department of Physiology, Biochemistry and Pharmacology, College of Veterinary Medicine, University of Mosul, Mosul, Iraq

\begin{tabular}{l} 
Article information \\
\hline Article history: \\
Received May 12, 2020 \\
Accepted July 14, 2020 \\
Available online June 23, 2021 \\
\hline Keywords: \\
Age-related \\
Analgesia \\
Anesthesia \\
Chickens \\
Ketamine \\
\hline Correspondence: \\
Y.J. Mousa \\
yarub204@ uomosul.edu.iq
\end{tabular}

\begin{abstract}
Little works of literature studied the anesthetic effect of ketamine in different ages of broiler chickens, hence this study intended to examine these alterations in chickens at different ages. The doses of ketamine that causes hypnosis in $50 \%$ of the chickens (hypnotic ED50) were $7.90,7.90$ and $6.80 \mathrm{mg} / \mathrm{kg}$, intramuscular (IM) at 10, 20 and 40-day-old chickens, respectively, whereas the doses that resulted in analgesia in $50 \%$ of the chickens (analgesic ED50) were 12.92, 12.92 and $6.50 \mathrm{mg} / \mathrm{kg}$, IM. The onset, duration and recovery from ketamine hypnosis were in an age-dependent manner and significantly longer at 40day-old, although the depth and sensitivity of chickens to ketamine hypnosis rises as the age advancing forward. Ketamine analgesia is more effective at 40-day-old. There are neurobehavioral deficits, according to the age of chickens when injecting ketamine in a subtle dose of $1 \mathrm{mg} / \mathrm{kg}$, IM. The concentrations related to alanine transaminase (ALT) and aspartate transaminase (AST), tested in the serum, reveal that the 40-day-old chicken group differs significantly from 10 and 20-day-old chicken's groups which all treated with single ketamine dose $(25 \mathrm{mg} / \mathrm{kg}$, IM). In conclusion, the present work discovered that ketamine's efficacy, including hypnosis, analgesia and neurobehavioral activity will be increased as the age is progressing, suggesting that the veterinarians need to take it into account when preparing the dose regimen of ketamine anesthesia for different ages of animals.
\end{abstract}

DOI: $10.33899 /$ ijvs.2020.127100.1458, (C2021, College of Veterinary Medicine, University of Mosul.

This is an open access article under the CC BY 4.0 license (http://creativecommons.org/licenses/by/4.0/).

\section{Introduction}

Ketamine is used broadly for induction of anesthesia in veterinary surgery, offers hypnosis with weak analgesia via blocking $\mathrm{N}$-methyl D-aspartate (NMDA) receptors that located at the nervous tissue, producing a reduce in the calcium ion inflowing inside nervous cells with eventual anesthesia $(1,2)$. Age acts vital role concerning the pharmacological responses to various drugs (like affinity and efficacy) and considered a physiological factor that affect the responses of the body to various drugs, especially the neuroacting agents due to its relation to up and down regulation of the receptor protein and the effect of oxidative stressinducing degenerative disorders of the neurons related to different ages beside its impact on the blood-brain barrier $(3,4)$. Ketamine may interact with different facilitating effects on the release of hippocampal acetylcholine (Ach) neurotransmitter and this is attributed to the aging process which can inhibit the ability to recover from the anesthetic effect (5). Certain functional enhancements in adult mice, for example, with different growth hormone signals, may be due to NMDA receptor improvement are proposed in previous study (4). Insulin like growth factor-1 (IGF-1) and growth hormone $(\mathrm{GH})$ fulfill biological portion to age-related vascular density and propose that vascular thickness may have significant changes of concerns for age in blood flow of the cerebrum and brain function (6), specifies a possible important role in the age related reverse of rodent's behavior for IGF-1 (7). The detached aim was to investigate the ketamine anesthetic efficacy and its correlation with different ages of broiler chickens to address the effect of age on ketamine narcosis and its neurobehavioral changes. 


\section{Materials and methods}

\section{Chickens and drug preparation}

Broiler chickens (both genders) of ages 10, 20 and 40days were included in this study with mean body weight between $0.15-1.7 \mathrm{~kg}$. They held in pens of $30-34^{\circ} \mathrm{C}$ temperatures with incessant light, and the ground litter involved of wood shreds. Chickens had allowed admission to water and food. The ketamine (5\% Hameln pharmaceuticals, Germany) was equipped at $5 \mathrm{ml} / \mathrm{kg}$ to be given IM.

\section{Animal ethics}

The scientific committee of the College of Veterinary Medicine at University of Mosul has valid and authenticate this study for the application of experimental chicken and for ethical concerns.

\section{Ketamine's hypnotic ED50 in chickens at different ages}

The hypnotic $\mathrm{ED}_{50}$ dose of ketamine was valued according to up and down pattern at different ages 10,20 and 40-days-old (8). The first dose of ketamine injected was 12 $\mathrm{mg} / \mathrm{kg}$, IM hanged on pilot study. Chickens were watched alone along with $2 \mathrm{~h}$ following ketamine administration (to check for righting reflex loss which indicates the hypnotic effect) and then, the ketamine's dosages reduced or raised 3 $\mathrm{mg}$ which hangs on for appearance or absence of the hypnosis.

\section{Measurement the analgesic ED $_{50}$ for ketamine in chickens at different ages}

The $\mathrm{ED}_{50}$ value of ketamine that causes analgesia in $50 \%$ of the chickens was measured according to the above method defined in the first trial at different ages 10, 20 and 40-daysold (8). Ketamine's analgesia recorded via an electro stimulator apparatus (scientific research, UK) for induction of ache sensation in chickens (9-17). The ketamine's first IM dose injected at $12 \mathrm{mg} / \mathrm{kg}$ by elevates or reduces $3 \mathrm{mg} / \mathrm{kg}$ of the dosage. In this experiment, the pain in the chickens (categorized by distress call) was recorded as a voltage for each one individually before and after 10 minutes of ketamine injection $(9,10,17)$. Ketamine has seen to result in an anti-nociceptive effect when the recorded voltage after injection was raised in relative to voltage measured prior ketamine injection (The chicken will be assigned as $\mathrm{X}$ ), and if there is no analgesia, the chicken will be marked as $\mathrm{O}$. Then the table value was extracted from Dixon's table (8) to determine the $\mathrm{ED}_{50}$ dose of ketamine.

\section{Effect of single anesthetic dose of ketamine hypnosis at different ages of chickens}

The hypnotic effects of ketamine (losing the righting reflex) were monitored in three age-groups of chickens 10 , 20 and 40-day-old chickens, that treated with single IM dose of ketamine at $25 \mathrm{mg} / \mathrm{kg}$. The dose of ketamine was adopted from the its values related to hypnotic and analgesic $\mathrm{ED}_{50 \mathrm{~s}}$. Each individual chicken was observed to register the hypnosis in addition to the duration and the recovery from hypnosis in all ages groups $(18,19)$.

\section{Effect of single anesthetic dose of ketamine analgesia at different ages of chickens}

The difference in the analgesic effect of ketamine was determined throughout all studied ages of chickens by applying one IM dose of ketamine at $25 \mathrm{mg} / \mathrm{kg}$ in response to the analgesic $\mathrm{ED}_{50}$ dose of ketamine. Voltage of the electro-stimulator device that produce nociception registered prior and post ten min related to ketamine administration for every chicken independently. The delta voltages for each group were also considered for estimation (9).

\section{Assessment of subtle neurobehavioral effects induced by ketamine in different ages of broilers chickens}

Different measurements of open-field were used to investigate the neurobehavioral changes of ketamine in different ages 10, 20 and 40 days $(20,21)$. Activity in the open field for chicken watched thirty min post IM ketamine treating at $1 \mathrm{mg} / \mathrm{kg}$ and this dose did not produce any apparent effect so that, the subtle effect determined resembling the neurobehavioral deficits (22). Each chicken was individually placed in middle of the arena with 50 grams of grains spread at the surface. The listed below behavioral parameters estimated after thirty min of ketamine injection within 5-minute period as designated earlier $(21,22)$. The open-field parameters included moving latency in seconds; sum of escapes jumps; frequency of defecations; distress calls scores and pecking behavior scores. After this test, every chicken undergoing test of tonic immobility $(20,22)$ through picking the chicken by two hands and setting it 15 seconds on a table. The hands will withdraw and then, the standing-up of chicken itself unassisted were registered.

\section{Measurement of serum ALT and AST concentrations in the chickens treated with ketamine at the ages of 10, 20 and 40-days-old}

Following 2 hours of IM injection of ketamine at 25 $\mathrm{mg} / \mathrm{kg}$, the blood was gained from the vein of each chicken at different studied ages, then the blood collected in gel tubes and undergoing centrifugation to alleviate of serum that freeze awaiting analysis during 48 hours. Serum ALT (23) and AST (24) concentrations were determined by using Chemistry Analyzer Smart-150 apparatus (GenoTEK, USA).

\section{Statistics}

Parametric statistical analysis was directed by variance analysis of one way (ANOVA) tracked by the $\operatorname{LSD}(25,26)$. The data of non-parametric origin undergoes analysis by the Fisher exact probability and Mann-Whitney U tests $(26,27)$. The probability (p) of the results was considered significantly differs at less than $5 \%$. 
Results

Ketamine's hypnotic ED 50 in chickens at ages of 10, 20 and 40-days-old

The doses of ketamine that cause hypnosis in $50 \%$ of the chickens were $7.90,7.90$ and $6.80 \mathrm{mg} / \mathrm{kg}, \mathrm{IM}$ at 10,20 and 40-day-old respectively, and the fastest onset of hypnosis was at age 40-day-old as shown in table 1 .

\section{Analgesic ED $D_{50}$ value of ketamine in chickens at different ages}

Table 2 shows the doses of ketamine that caused analgesia in $50 \%$ of the chickens were 12.92, 12.92 and 6.50 $\mathrm{mg} / \mathrm{kg}, \quad \mathrm{IM}$ at 10,20 and 40 days-old chickens correspondingly. As reported increase in ketamine efficacy that causes analgesia at age 40-day-old chicken in comparison to younger ages.

\section{Single dose of ketamine and its effect on hypnosis at} different ages of chickens

The onset, duration and recovery from ketamine hypnosis were $2.17,22.50$ and 29.83 minutes respectively at 10-dayold of chickens. The same measurements were 3.50, 25.00 and 69.67 minutes respectively at 20-day-old, while the onset, duration and recovery from ketamine hypnosis were 2.83, 46.17 and 96.67 minutes respectively at 40-day-old. Table 3 reflects that the results of ketamine hypnosis were in an age dependent manner and the shorter onset with significantly longer duration and recovery of hypnosis were at 40-day-old, although the depth and sensitivity of chickens to ketamine hypnosis increases as the age is progress.

\section{Ketamine's single dose and its analgesic effect at different ages of chickens}

The 10-day-old chickens displays that the volts recorded (prior, and post 10 minutes of ketamine treatment) was significantly different (9.17 and 13.83 volts respectively). The same measurements were 10.67 and 15.17 volts respectively at 20-day-old chickens whereas these volts were 15.00 and 23.00 volts respectively at 40 -day-old. The results indicate the analgesic effect of ketamine is greater and more effective at 40-day-old chickens as shown in table 4.

\section{Assessment of subtle neurobehavioral effects induced by ketamine in different ages of chickens}

The IM administration of ketamine at $1 \mathrm{mg} / \mathrm{kg}$ causes many (non-significant) neurobehavioural changes at different ages, especially in relation to frequency of defecation and escape jump except the latency to move and tonic immobility response test (which are significant at 40days-old). All these changes refer to increase in the subtle depressant effect of ketamine as the age progressing forward (table 5).

\section{Serum ALT and AST in the different ages of chickens treated with ketamine}

The serum concentrations of ALT and AST were found close to normal ranges of chickens. The serum ALT and AST in 40-day-old group significantly different (at $\mathrm{P}<5 \%$ ) from 10 and 20-days-old groups after treatment with $25 \mathrm{mg} / \mathrm{kg}$, IM ketamine as shown in table 6 .

Table 1: Hypnotic $\mathrm{ED}_{50 \mathrm{~s}}$ of ketamine for different ages of chickens

\begin{tabular}{lccc}
\hline Parameter & 10 -days old & 20 -days old & 40 -days old \\
\hline Hypnotic ED S0 $_{5}$ value, IM & $7.90 \mathrm{mg} / \mathrm{kg}$ & $7.90 \mathrm{mg} / \mathrm{kg}$ & $6.80 \mathrm{mg} / \mathrm{kg}$ \\
Doses applied & $6-12 \mathrm{mg} / \mathrm{kg}$ & $6-12 \mathrm{mg} / \mathrm{kg}$ & $6-12 \mathrm{mg} / \mathrm{kg}$ \\
Beginning dose & $12 \mathrm{mg} / \mathrm{kg}$ & $12 \mathrm{mg} / \mathrm{kg}$ & $12 \mathrm{mg} / \mathrm{kg}$ \\
Final dose & $9 \mathrm{mg} / \mathrm{kg}$ & $9 \mathrm{mg} / \mathrm{kg}$ & $9 \mathrm{mg} / \mathrm{kg}$ \\
\pm in dose & $3 \mathrm{mg} / \mathrm{kg}$ & $3 \mathrm{mg} / \mathrm{kg}$ & $3 \mathrm{mg} / \mathrm{kg}$ \\
Chicken's number & $6(X X O X X)^{*}$ & $6(X X O X X)^{*}$ & $6(X X O X O X)^{*}$ \\
Beginning of hypnosis & $1-5 \mathrm{~min}$. & $2-7 \mathrm{~min}$. & $1-3 \mathrm{~min}$. \\
\hline
\end{tabular}

${ }^{*} \mathrm{X}=$ hypnosis, $\mathrm{O}=$ no hypnosis.

Table 2: Analgesic $\mathrm{ED}_{50 \mathrm{~s}}$ of ketamine for different ages of chickens

\begin{tabular}{lccc}
\hline Parameter & 10 -days old & $20-$ days old & 40 -days old \\
\hline ED $D_{50}$ value, IM & $12.92 \mathrm{mg} / \mathrm{kg}$ & $12.92 \mathrm{mg} / \mathrm{kg}$ & $6.50 \mathrm{mg} / \mathrm{kg}$ \\
Doses applied & $9-15 \mathrm{mg} / \mathrm{kg}$ & $9-15 \mathrm{mg} / \mathrm{kg}$ & $6-12 \mathrm{mg} / \mathrm{kg}$ \\
Beginning dose & $12 \mathrm{mg} / \mathrm{kg}$ & $12 \mathrm{mg} / \mathrm{kg}$ & $12 \mathrm{mg} / \mathrm{kg}$ \\
Final dose & $12 \mathrm{mg} / \mathrm{kg}$ & $12 \mathrm{mg} / \mathrm{kg}$ & $6 \mathrm{mg} / \mathrm{kg}$ \\
\pm in dose & $3 \mathrm{mg} / \mathrm{kg}$ & $3 \mathrm{mg} / \mathrm{kg}$ & $3 \mathrm{mg} / \mathrm{kg}$ \\
Chicken's number & $5(X O O X O)^{*}$ & $5(X O X O){ }^{*}$ & $5(X O X X X){ }^{*}$ \\
\hline
\end{tabular}

${ }^{*} \mathrm{X}=$ analgesia, $\mathrm{O}=$ no analgesia. 
Table 3: Single dose of ketamine and its effect on hypnosis at different ages of chickens

\begin{tabular}{|c|c|c|c|}
\hline $\begin{array}{l}\text { Ages } \\
\text { (days) }\end{array}$ & $\begin{array}{l}\text { Hypnosis } \\
\text { beginning in } \\
\text { min }\end{array}$ & $\begin{array}{c}\text { Hypnosis } \\
\text { duration in } \\
\text { min }\end{array}$ & $\begin{array}{l}\text { Recovery in } \\
\text { min }\end{array}$ \\
\hline 10 & $2.17 \pm 0.17$ & $22.50 \pm 2.84$ & $29.83 \pm 2.43$ \\
\hline 20 & $3.50 \pm 0.22 *$ & $25.00 \pm 2.01$ & $69.67 \pm 4.80$ * \\
\hline 40 & $2.83 \pm 0.31$ & $46.17 \pm 4.77^{*, a}$ & $96.67 \pm 2.22^{*}, \mathrm{a}$ \\
\hline
\end{tabular}

Table 4: Single dose of ketamine for induction of analgesia at different ages of chickens

\begin{tabular}{lccc}
\hline $\begin{array}{l}\text { Ages } \\
\text { (days) }\end{array}$ & $\begin{array}{c}\text { Volts before } \\
\text { injection }\end{array}$ & $\begin{array}{c}\text { Volts after 10 } \\
\text { minutes of } \\
\text { injection }\end{array}$ & $\Delta$ Voltage \\
\hline 10 & $9.17 \pm 0.48$ & $13.83 \pm 0.54^{+}$ & $4.67 \pm 0.88$ \\
20 & $10.67 \pm 0.49$ & $15.17 \pm 1.08^{+}$ & $4.50 \pm 1.06$ \\
40 & $15.00 \pm 1.03^{*}, \mathrm{a}$ & $23.00 \pm 0.93^{+, *}, \mathrm{a}$ & $8.00 \pm 1.65$ \\
\hline
\end{tabular}

The values represented as Average \pm Std. Error for 6 chickens/group. Pain sensation was measured by electrostimulator pre- and post-10 minutes of treating of ketamine $\left(25 \mathrm{mg} / \mathrm{kg}\right.$, IM) for all the groups. ${ }^{*}$ Differs significantly from 10 days-old $(\mathrm{P}<5 \%)$. ${ }^{\mathrm{a}}$ Differs significantly from 20 days-old $(\mathrm{P}<5 \%) .{ }^{+}$Differs significantly from the same group (volts pre-injection) $(\mathrm{P}<5 \%)$.

Table 5: Neurobehavioral parameters of ketamine at different ages

\begin{tabular}{lccc}
\hline \multirow{2}{*}{ Neurobehavioral parameters } & \multicolumn{3}{c}{ Ages of chickens } \\
\cline { 2 - 4 } & 10 -days old & 20 -days old & 40 -days old \\
\hline Beginning of move (seconds) & $22.67 \pm 14.34$ & $21.33 \pm 11.05$ & $52.33 \pm 12.76^{*}, \mathrm{a}$ \\
Tonic immobility (seconds) & $37.50 \pm 13.82$ & $76.00 \pm 23.58$ & $220.50 \pm 69.72^{*}, \mathrm{a}$ \\
Frequency of defecation & $0.83 \pm 0.17$ & $0.00 \pm 0.00$ & $0.33 \pm 0.21$ \\
Escape jump's number & $0.00 \pm 0.00$ & $0.00 \pm 0.00$ & $0.33 \pm 0.21$ \\
Scores of distress calls & $2.00 \pm 0.37$ & $0.00 \pm 0.00$ & $0.00 \pm 0.00$ \\
Pecking scores & $0.00 \pm 0.00$ & $0.00 \pm 0.00$ & $0.00 \pm 0.00$ \\
\hline
\end{tabular}

The values represented as Average \pm Std. Error for 6 chickens/group. The Test was conducted after 30 minutes of ketamine injection at a subtle dose $\left(1 \mathrm{mg} / \mathrm{kg}\right.$, IM). ${ }^{*}$ Differs significantly from 10 days-old $(\mathrm{P}<5 \%)$. ${ }^{\text {a }}$ Differs significantly from 20 daysold $(\mathrm{P}<5 \%)$.

Table 6: Serum ALT and AST concentration in chicks treated with ketamine at different ages

\begin{tabular}{lcc}
\hline Ages (days) & ALT (Unit/Liter) & AST (Unit/Liter) \\
\hline 10 & $12.67 \pm 1.23$ & $212.33 \pm 3.81$ \\
20 & $10.33 \pm 1.23$ & $200.33 \pm 2.60$ \\
40 & $4.00 \pm 0.688^{*, a}$ & $166.50 \pm 9.49^{*, a}$ \\
\hline The values represented Average \pm Std. Error for 6 \\
chickens/dose group. Blood samples were obtained after 2 \\
hours from ketamine therapy at $25 \mathrm{mg} / \mathrm{kg} .{ }^{*}$ Differs \\
significantly from 10 day-old $(\mathrm{P}<5 \%) .{ }^{\text {a }}$ Differs significantly \\
from 20 day-old $(\mathrm{P}<5 \%)$.
\end{tabular}

\section{Discussion}

Ketamine considered a widely usage drug for anesthetic induction of surgical operations of the veterinary medicine field and produces good hypnotic with weak analgesia by its blocking effect of NMDA receptor in the nervous tissue, leading to an inhibition of the calcium current inflowing the neuronal cells causes induction the anesthesia $(1,2)$. Ketamine used with xylazine in chickens and considered appropriate anesthesia for pain killing procedures in pigeons (28). However, it is preferable to combine ketamine with diazepam as this combination is moderately safer (29). The hypnotic and analgesic $\mathrm{ED}_{50 \text { s }}$ of ketamine measured in this trial at different ages of chicken were in close to prior study in the same field $(11,30)$. In current work, the hypnotic besides analgesic ketamine's effects were enhanced in the efficacy as the ages of the chicken progress and this could be attributed to the effect of ketamine on the release of Ach neurotransmitter from the hippocampus as reported previously in older rats compared to the youngers (5). Another reason might be attributed to a regional and specific alteration of NMDA receptor with age and because IGF-1 modulates the NMDA receptor expression suggesting a changes in the heterogeneity of NMDA receptors can lead to modification of functional receptors which are relevant to aging process (3) such as the occurrence of receptor upregulation. Some of the functional enhancements in older chickens, for example, with different growth hormone signals, may be due to NMDA receptor improvement that found in mouse model (4). Growth hormone and IGF-1 work a vital role in age-related vessels density and propose that reductions in vascular thickness may have significant concerns for age-related involvement related to cerebral blood flow and brain function (6), which possibly have an important role in the opposite of age dependent behavioral 
deficits in chickens for IGF-1 as found in rodents (7). Other factors and age have a significant effect on the ketamine's availability, reflected in modification of the pharmacokinetics criteria, metabolism of liver of the drug and its pharmacodynamics (31). Intraperitoneal ketamine injections for both sex revealed a significant relationship between increased age and the duration of hypnosis and this alteration in hypnosis appeared to be associated with changes in production of ketamine cyclohexanone oxidation metabolites (32) and the age-related effects of NMDA may be related to impaired release of glycine (33). Some behavioral changes explored in this study were associated with ketamine anesthesia that recorded in other study (34). Ketamine administration showed differential neurobehavioral effects on activity levels of chickens depending on the animal's age which is correspondence with another study in rats (35). The serum concentrations of ALT and AST were found close to normal ranges of chickens (36) which indicate the effect of ketamine on the liver function at different ages, and the 40-day-old chickens group differs significantly from 10 and 20-days-old chickens (that all treated with one ketamine's dosage $25 \mathrm{mg} / \mathrm{kg}$, IM) suggesting alteration in metabolism, and a possible pharmacokinetics, of ketamine during that ages of chickens.

\section{Conclusion}

The present work discovered that ketamine's efficacy, including hypnosis, analgesia and neurobehavioral activity will be increased as the age is progressing forward, suggesting that the veterinarians need to take it into account when preparing the dose regimen of ketamine anesthesia for different ages of animals.

\section{Acknowledgements}

The authors thankful for the College of Veterinary Medicine which belongs to the University of Mosul for providing resources needed to accomplish the research.

\section{Conflict of interest}

The authors declare there is no conflict of interest.

\section{References}

1. Carter J, Story DA. Veterinary and human anaesthesia: an overview of some parallels and contrasts. Anaesth Intensive Care. 2013;41:710-718. DOI: $10.1177 / 0310057 \mathrm{X} 1304100605$

2. Molina AM, Moyano MR, Serrano-Rodriguez JM, Ayala N, Lora AJ, Serrano-Caballero JM. Analyses of anaesthesia with ketamine combined with different sedatives in rats. Vet Med. 2015;60(7):368375. DOI: 10.17221/8384-VETMED

3. Sonntaga WE, Bennetta SA, Khana AS, Thorntona PL, Xu X, Ingrama RL, Brunso-Bechtold JK. Age and insulin-like growth factor-1 modulate $\mathrm{N}$-methyl-D-aspartate receptor subtype expression in rats.
Brain Res Bullet. 2000;51(4):331-338. DOI: 10.1016/s03619230(99)00259-2

4. Magnusson KR, Das SR, Kronemann D, Bartke A, Patrylo PR. The Effects of Aging and Genotype on NMDA Receptor Expression in Growth Hormone Receptor Knockout (GHRKO) Mice. J Gerontol A Biol Sci Med Sci. 2011;66(6):607-619. DOI: 10.1093/gerona/glr024

5. Wang Y, Kikuchi T, Sakai M, Wu JL, Sato K, Okumura F. Age-related modifications of effects of ketamine and propofol on rat hippocampal acetylcholine release studied by in vivo brain microdialysis. Acta Anaesthesiol Scand. 2000;44(1):112-127. DOI: 10.1034/j.13996576.2000.440120.x

6. Sonntag WE, Lynch CD, Cooney PT, Hutchins PM. Decreases in Cerebral Microvasculature with Age Are Associated with the Decline in Growth Hormone and Insulin-Like Growth Factor 1. Endocrinol. 1997;138(8):3515-3520. DOI: 10.1210/endo.138.8.5330

7. Markowska AL, Mooneya M, Sonntag WE. Insulin-like growth factor1 ameliorates age-related behavioral deficits. Neurosci. 1998;87(3):559-569. DOI: 10.1016/s0306-4522(98)00143-2

8. Dixon WJ. Efficient analysis of experimental observations. Annu Rev $\begin{array}{llll}\text { Pharmacol Toxicol. 1980; 20:441-462. DOI: } & \end{array}$ 10.1146/annurev.pa.20.040180.002301

9. Mousa YJ, Mohammad FK. The analgesic efficacy of xylazine and dipyrone in hydrogen peroxide-induced oxidative stress in chicks. Iraqi J Vet Sci. 2012;26(2):69-76. DOI: 10.33899/ijvs.2012.67444

10. Mousa YJ. Anaesthetic properties of ketamine in chicks stressed with hydrogen peroxide. Vet Med. 2014;59(8):369-375. DOI: 10.17221/7656-VETMED

11. Mousa YJ, Al-Zubaidy MHI. Anesthetic efficacy of ketamine, ketamine-tramadol and ketamine-ketorolac in the chicks. Iran J Vet Res. 2019;20(1):33-38. DOI: 10.22099/ijvr.2018.29755.4496

12. Naser AS, Amin YM. Analgesic effect of silymarin in chicks. Iraqi $\mathbf{J}$ Vet Sci. 2019;33(2):273-276. DOI: 10.33899/ijvs.2019.162906

13. Shaban KhA, Ibrahim MH, Faris GA. Evaluation of the antinociceptive effect of xylazine and it's interaction with metoclopramide in the acute pain model in mice. Iraqi J Vet Sci. 2020;34(2):383-388. DOI: 10.33899/ijvs.2019.126070.1226

14. Al-Abdaly YZ, Al-Hamdany EK, Al-Kennany ER. Toxic effects of butylated hydroxytoluene in rats. Iraqi J Vet Sci. 2021;35(1):121-128. DOI: $10.33899 /$ ijvs.2020.126435.1322

15. Al-Abdaly YZ, Saeed MG, Al-Hashemi HM. Effect of methotrexate and aspirin interaction and its relationship to oxidative stress in rats. Iraqi J Vet Sci. 2021;35(1):151-156. DOI: 10.33899/ijvs.2020.126490.1335

16. Mousa YJ. Etomidate anesthesia in chicks: Effect of xylazine. J Hellen Vet Med Soc. 2020;71(4):2463-2470. DOI: 10.12681/jhvms.25921

17. Mousa YJ, Mahmood MB, Mohammad MS. Administration of ketamine with the central and peripheral analgesics for induction of balanced anesthesia in the chicks. Earth Environ Sci. 2019;388:012021. DOI: $10.1088 / 1755-1315 / 388 / 1 / 012021$

18. Klinger W. Developmental aspects of enzyme induction and inhibition. Pharmacol Ther. 1987;33(1):55-61. DOI: 10.1016/01637258(87)90028-3

19. Al-Zubaidy MHI, Mohammad FK. Metoclopramide induced central nervous system depression in the chicken. BMC Vet Res. 2005;1:6-10. DOI: $10.1186 / 1746-6148-1-6$

20. Hennig CW, Fazio JK, Hughes CA, Castaldi WR, Spencer BD. Duration of tonic immobility in chickens as a function of alpha adrenergic receptor stimulation and blockade. Pharmacol Biochem Behav. 1984;20:731-738. DOI: 10.1016/0091-3057(84)90192-8

21. Mohammad FK, Mousa YJ, Hasan MM. Acute toxicity and neurobehavioral effects of diphenhydramine in chicks. J Poult Sci. 2012;49(1):51-56. DOI: $10.2141 /$ jpsa.011050

22. Mohammad FK, Faris GA-M. Behavioral effects of acute manganese chloride administration in chickens. Biol Trace Elem Res. 2006;110:265-274. DOI: 10.1385/BTER:110:3:265

23. Reitman S, Frankel S. A colorimetric method for the determination of serum glutamic oxaloacetic and glutamic pyruric transaminase. Am J Clin Path. 1957;28:56-63. DOI: 10.1093/ajcp/28.1.56 
24. Plummer DT. An introduction to practical Biochemistry. New York: McGrew-Hill Co Inc; 1987. 182-188 p. DOI: 10.1016/03074412(88)90082-9

25. Petrie A, Watson P. Statistics for Veterinary and Animal Sciences. Oxford: Blackwell Science; 2013. 90-140 p. DOI: $10.1136 /$ vr.f7415

26. Kuss O, Hoyer A, Solms A. Meta-analysis for diagnostic accuracy studies: a new statistical model using beta-binomial distributions and bivariate copulas. Stat Med. 2014;33, (1):17-30. DOI: 10.1002/sim.5909

27. Kvam PH, Vidakovic B. Nonparametric Statistics with Applications to Science and Engineering. New Jersey: John Wiley and Sons Inc; 2007. 115-139 p. DOI: $10.1002 / 9780470168707$

28. Durrani UF, Ashraf M, Khan MA. A comparison of the clinical effects associated with xylazine, ketamine, and a xylazine-ketamine cocktail in pigeons (Columba livia). Turk J Vet Anim Sci. 2009;33(5):413-417. DOI: $10.3906 /$ vet-0805-7

29. Mahmud MA, Shaba P, Yisa HY, Gana J, Ndagimba R, Ndagi S. Comparative efficacy of Diazepam, Ketamine, and DiazepamKetamine combination for sedation or anesthesia in cockerel chickens. J Adv Vet Anim Res. 2014;1(3):107-113. DOI: 10.5455/javar.2014.a24

30. Welkos S, O'Brien A. Determination of median lethal and infectious doses in animal model systems. Methods Enzymol. 1994;235:29-39. DOI: $\underline{10.1016 / 0076-6879(94) 35128-7}$

31. Giroux MC, Santamaria R, Hélie P, Burns P, Beaudry F, Vachon P. Physiological, pharmacokinetic and liver metabolism comparisons between 3-, 6-, 12- and 18-month-old male Sprague Dawley rats under ketamine-xylazine anesthesia. Exper Anim. 2016;65(1):63-75. DOI: 10.1538/expanim.15-0039

32. Waterman AE, Livingston A. Effect of age and sex on ketamine anesthesia in rat. $\mathrm{Br} \mathrm{J}$ Anaesth. 1978;50:885-890. DOI: 10.1093/bja/50.9.885

33. Pittaluga A, Fedele E, Risiglione C, Raiteri M. Age-related decrease of the NMDA receptor-mediated noradrenaline release in rat hippocampus and partial restoration by D-cycloserine. Europ $\mathrm{J}$ Pharmacol. 1993;231(1):129-134. DOI: 10.1016/0014-2999(93)90693-c

34. Coetzee JF, Gehring R, Tarus-Sang J, Anderson DE. Effect of subanesthetic xylazine and ketamine ('ketamine stun') administered to calves immediately prior to castration. Vet Anaesth Analg. 2010;37:566-578. DOI: $10.1111 / j .1467-2995.2010 .00573 . x$

35. Wilson C, Kercher M, Quinn B, Murphy A, Fiegel C, McLaurin A. Effects of age and sex on ketamine-induced hyperactivity in rats. Physiol Behav. 2007;91(2-3):202-207. DOI: 10.1016/j.physbeh.2007.02.010

36. Cruz CE, Freitas ER, Braz NM, Salles RP, da Silva ING. Blood parameters and enzymatic and oxidative activity in the liver of chickens fed with calcium anacardate. Rev Ciên Agron. 2018;49(2):343-352. DOI: $\underline{10.5935 / 1806-6690.20180039}$

\section{التأثير التخديري للكيتامين وعلاقته بالعمر في الدجاج}

\author{
يعرب جعفر موسى، منى حازم الزبيدي و سوسن محمد أمين \\ فرع الفسلجة والكيمياء الحياتية والأدوية، كلية الطب البيطري، جامعة \\ الموصل، الموصل، العر اق المباء
}

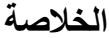

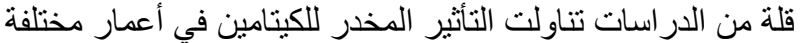

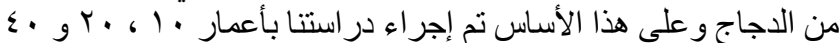

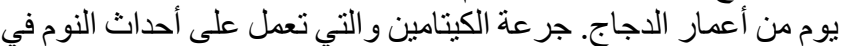

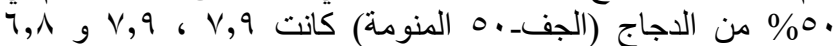

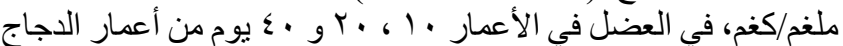

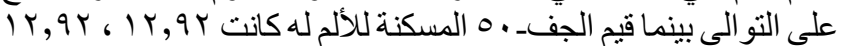

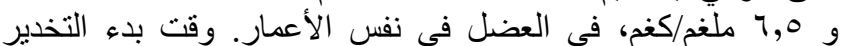

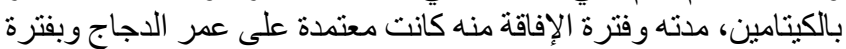

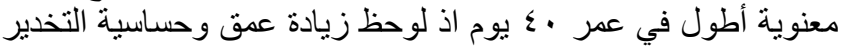

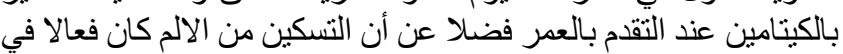

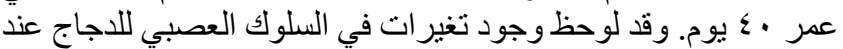

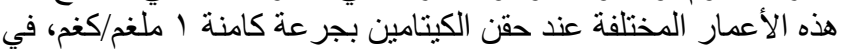

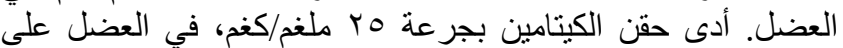

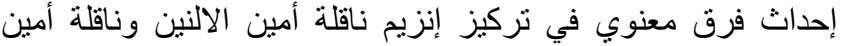

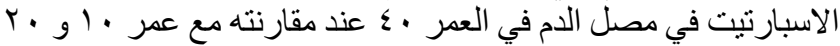
من عمر الدجاج. استتنج في هذه الدراسة أن فئ فعالية الكيتامين التخديرية،

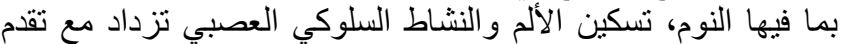

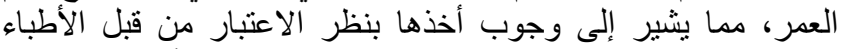
البيطريين عند إعداد جرعة التخدير بالكيتامين في الأعمار المختلفة الأنة

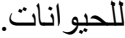

